\title{
TITANIUM PIGMENT IN TISSUES OF DRUG ADDICTS: REPORT OF 5 NECROPSIED CASES
}

\author{
Marcus Aurelho de Lima, Vitorino Modesto dos Santos, Samia Demachki and \\ Javier Lazo
}

LIMA MA de et al. - Titanium pigment in tissues of drug addicts: report of 5 necropsied cases. Rev. Hosp. Clín. Fac. Med. S. Paulo 59(2):86-88, 2004.

The aim of this report is to describe the anatomic-pathologic findings from necropsies of 5 drug addicts with titanium pigment in several organs after chronic intravenous injection of crushed propoxyphene hydrochloride tablets. Samples from liver, spleen, lungs, lymph nodes, and bone marrow were obtained, and after being grossly studied, they were submitted to evaluation using common light and polarized microscopy. In all 5 cases, a pigment with characteristics of titanium dioxide was found within tissue samples of the organs studied. Our findings suggest that research concerning titanium pigment within body tissues should be enhanced, considering the potential contribution of this morphologic data to forensic pathology.

KEY WORDS: Titanium. Drug addiction. Propoxyphene hydrochloride. Talc. Necropsy.

Titanium dioxide $\left(\mathrm{TiO}_{2}\right)$ is a mineral that is also called rutile (Latin rutilus: reddish or pink). It is usually found with a little iron and is usually a reddish-brown color, and it constitutes a major source of titanium. Some drug addicts intravenously inject crushed tablets of propoxyphene hydrochloride, which contain talc (basic silicate of magnesium), calcium, and titanium as excipients, and particles of these minerals can be found within tissue samples from their internal organs $^{1,2}$. Although talc granulomatosis has been described in association with intravenous injection of propoxyphene hydrochloride $^{2}$, we performed a literature review using the key words: titanium, drug addiction, propoxyphene hydrochloride, talc, and necropsy, and we found a single report of titanium pigment deposited in tissues of drug addicts $^{1}$. The exclusive aim of this re- port is to describe the anatomicpathologic findings from 5 additional cases of drug addicts with titanium pigment in several organs after chronic intravenous injection of crushed propoxyphene hydrochloride tablets.

\section{ANATOMIC-PATHOLOGIC FINDINGS}

Five white male adults, mean age 36 years, at least 2 years previously utilizing intravenous injections that contained crushed propoxyphene hydrochloride tablets, were submitted to

From the Discipline of Endocrinology; Department of Internal Medicine and Discipline of Pathology, Faculty of Medicine of the "Triângulo Mineiro" - Uberaba/MG, Brazil.

Received for publication on June 09, 2003. complete necropsy. In all the cases, titanium deposits were noted within the liver, spleen, lymph nodes, lungs, and bone marrow. Grossly, the deposits were seen as chalky streaks and dots (Figs. 1 and 2), and microscopically, the streaks and dots were disclosed within granule-laden macrophages. The granules appeared greenish-tan to black on hematoxylin-eosin staining (Figs. 3 and 4). The characterization of titanium pigment was based on its optical microscopy qualities - that is, appearing white with reflected light (Figs. 1 and 2), black with transmitted light (Figs. 3 and 4), and pink with polarized light ${ }^{1}$ (Figs. 5 and 6).

\section{DISCUSSION}

This report is in general agreement with the literature reporting titanium 


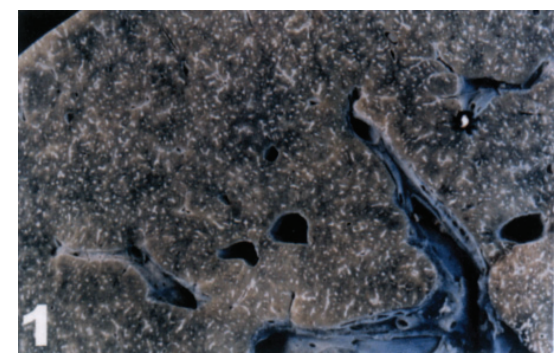

Figure 1 - Case 1: Liver grossly showing chalky streaks and dots with reflected light.

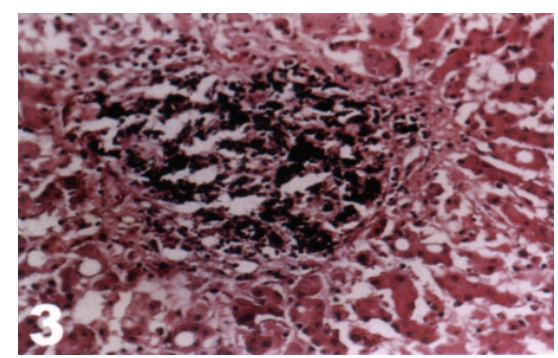

Figure 3 - Case 3. Liver sample showing black granules with transmitted light (HE, x100).

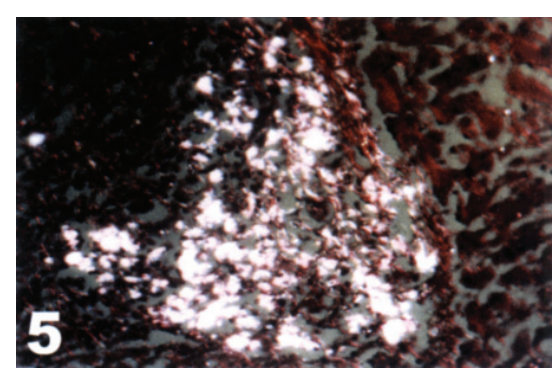

Figure 5 - Case 5: Liver granules appearing pinkish with polarized light (HE, x200).

pigment in organs of individuals with history of intravenous injection of propoxyphene hydrochloride ${ }^{1}$; how-

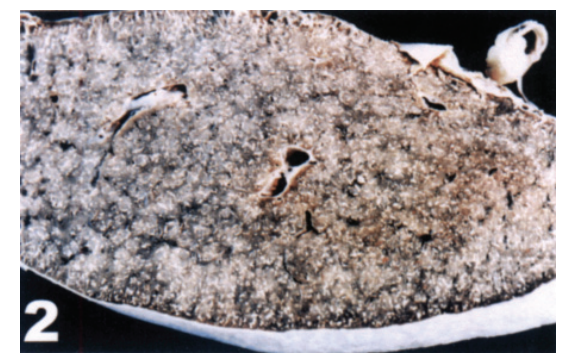

Figure 2 - Case 2: Gross aspect of spleen with whitish dots with reflected light.

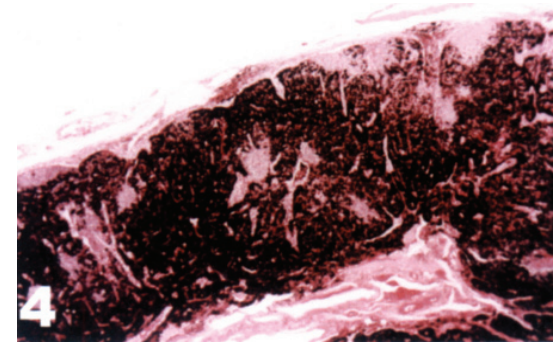

Figure 4 - Case 4: Lymph node with disseminated black pigment with transmitted light (HE, x25).

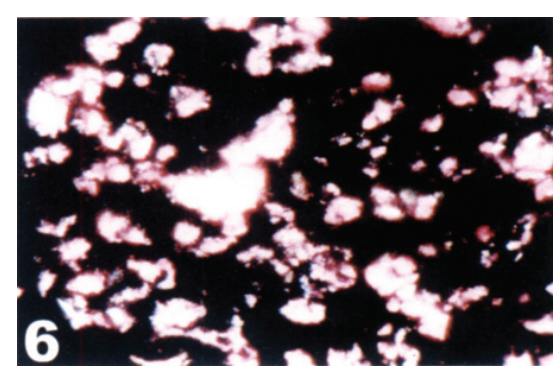

Figure 6 - Case 2: Pink color of spleen titanium granules with polarized light (HE, x400).

ever, we found the mineral deposits to be grossly white, while some authors have reported them as black ${ }^{1,3}$. Such difference in color could be, at least in part, explained by the presence of other elements associated with titanium in tissues ${ }^{4-6}$. Moreover, is not entirely clear if the finding of titanium pigment within several organs is always related to intravenous titanium injection for the following reasons: 1) this relationship may be not easily demonstrated in drug addicts; 2) patients with orthopedic prosthesis can show titanium pigment in the nearby soft tissues ${ }^{7}$ and in regional draining lymph nodes ${ }^{3}$, in addition to increased titanium concentrations in hairs ${ }^{8} ; 3$ ) occupational exposition to titanium dust may be associated with pulmonary deposition of white pigment (titanium dioxide), without local inflammatory changes ${ }^{9}$; 4) significant species differences in pulmonary responses to experimentally inhaled titanium dioxide particles have been observed in rodents $\left.{ }^{10} ; 5\right)$ dark granular pigment in macrophages of human gut-associated lymphoid tissue is rich in titanium dioxide $^{5}$; and 6) titanium and other trace elements may be found in samples from normal and cirrhotic livers ${ }^{4}$. As revealed by these facts, it seems that additional research is needed to better resolve this matter. Finally, the identification of titanium pigment in several organs may indicate illicit drug use, which could be useful in medico-legal investigations.

\section{RESUMO}

LIMA MA de e col. - Pigmento de titânio em tecidos de toxicômanos: relatos de cinco casos necropsiados. Rev. Hosp. Clín. Fac. Med. S. Paulo 59(2):86-88, 2004.

O objetivo deste relato é descrever os achados anatomopatológicos de cinco casos de toxicômanos com pigmento de titânio em vários órgãos, após injeção de comprimidos esmagados de cloridrato de propoxifeno. Foram obtidos fragmentos do fígado, baço, pulmões, linfonodos e medula óssea e, após a avaliação macroscópica, amostras foram submetidas à microscopia de luz comum e de luz polarizada. Em todos os cinco casos, foi encontrado um pigmento com características de dióxido de titânio nas amostras dos órgãos estudados. Nossos achados sugerem que a pesquisa sobre pigmento de titânio em tecidos corporais deva ser complementada, considerando-se a contribuição de dados morfológicos em Patologia Forense.

UNITERMOS: Titânio. Toxicomania. Cloridrato de propoxifeno. Talco. Necropsia. 


\section{REFERENCES}

1. Coelho Filho JC, Moreira R, Crocker PR. Identification of titanium pigment in drug addicts' tissues. Histopathology, 1991; 19:1902.

2. Cunha DF, Santos VM, Cunha SFC. Correlação anátomoclínica:granulomatose sistêmica por talco em drogadicto HIV negativo. Rev Ass Méd Bras 1999; 45:285-8.

3. Albores-Saavedra J, Vuitch F, Delgado R. Sinus histiocytosis of pelvic lymph nodes after hip replacement. A histiocytic proliferation induced by cobalt-chromium titanium. Am J Surg Pathol 1994; 18:83-90.

4. Milman N, Laursen J, Podenphant J. Trace elements in normal and cirrhotic human liver tissue. I. Iron, copper, zinc, selenium, manganese, titanium and lead measured by X-ray fluorescence spectrometry. Liver 1986; 6:111-7.

5. Powell JJ, Ainley CC, Harvey RS. Characterization of inorganic microparticles in pigment cells of human gut associated lymphoid tissue. Gut 1996; 38:390-5.
6. Ghandially FN, Walley VM. Pigments of the gastrointestinal tract: a comparison of light microscopic and electron microscopic findings. Ultrastruct Pathol 1995; 19:213-9.

7. Onodera K, Ooya K, Kawamura H. Titanium lymph node pigmentation in reconstruction plate system of a mandibular bone defect. Oral Surg Oral Med Oral Pathol 1993; 75:495-7.

8. Trinchi V, Nobis M, Cecchele D. Emission spectrophotometric analysis of titanium, aluminium, and vanadium levels in the blood, urine, and hairs of patients with total hip arthroplasties. Ital J Orthop Traumatol 1992; 18:331-9.

9. Rode LE, Ophus EM, Gylseth B. Massive pulmonary deposition of rutile after titanium dioxide exposure: Light-microscopical and physico-analytical methods in pigment identification. Acta Pathol Microbiol Scand 1981; 89:455-61.

10. Bermudez E, Mangum JB, Asgharian B. Long-term pulmonary responses of three laboratory rodent species to subchronic inhalation of pigmentary titanium dioxide particles. Toxicol Sci 2002; 70:86-97. 